\title{
FUNDAMENTALISME DAN MASA DEPAN IDEOLOGI POLITIK ISLAM
}

\author{
Abdul Chalik \\ Universitas Islam Negeri Sunan Ampel Surabaya, Indonesia \\ E-mail: achalik_el @yahoo.co.id
}

\begin{abstract}
This article elaborates the phenomenon of fundamentalism and the future of Islamic political ideology. Islamic ideology represents religious views, ideas and movements which aspire to bring Islam into practice in state and societal affairs. One variant of Islamic ideologies is fundamentalism which endeavors to return religious practices back to the pristine Islam based on the Qur'ân and al-Hadîth. Fundamentalism rejects all modes of understandding which are not based on the Qur'ân and al-Hadîth, and refuses secular methodology in interpreting the Qur'ân. This type of Islamic ideology found its momentum when Saudi Arabia regime officially adopted Wahhabism, and when Egyptian intellectuals were united to fight against modernity. Both Saudi Arabia and Egypt became seeding ground for fundamentalism. Some young muslim scholars who studied there became agents for the dissemination dan transmission of the fundamentalist ideology throughout the world. In Indonesia, this ideology have developed since independence and the drafting of the constitution. In the Indonesian context, resistence from traditionalist and nationalit groups were so strong that enable to dam up the spread of fundamentalis ideas. However, fundamentalist ideology remains an important challenge for the future of Indonesian Islam.
\end{abstract}

Keywords: Fundamentalism; Islamic ideology.

\section{Pendahuluan}

Perbincangan masalah ideologi tidak pernah akan habis seiring dengan semakin kuatnya pengaruh ilmu pengetahuan dalam kehidupan manusia. Diskursus ideologi selalu bersamaan dengan perkembangan ilmu pengetahuan, dan di ranah ilmu pengetahuan itu, ideologi memeroleh tempat untuk bersemayam, tumbuh subur, berdialektis dan terjadi inovasi-inovasi beragam. Bahkan menurut 
pandangan yang lebih radikal, justru ilmu pengetahuan berasal dari ideologi. Ideologi memberi bentuk dan legitimasi terhadap ilmu pengetahuan.

Dalam perkembangannya, ideologi memberi pengaruh yang cukup besar terhadap suatu bangsa dan negara. Munculnya blok aliran sosialis dan kapitalis dalam sistem kenegaraan merupakan bagian tak terpisahkan dari polarisasi pengaruh ideologi dalam suatu negara. Hampir semua masalah di dunia tidak bisa dilepaskan-atau sengaja dihubungkan dengan persoalan ideologis, baik ideologi kanan, kiri atau yang berada di antara keduanya.

Bagaimana dengan Islam? Islam adalah agama wahyu yang kebenarannya merupakan keniscayaan bagi setiap pemeluknya. Pada bagian tertentu Islam diterima secara as it is, tapi pada bagian lain Islam sudah menjadi bagian tak terpisahkan dari kehidupan manusia, menjadi tuntunan hidup, way of life bahkan menjadi ideologi. Masuknya Islam sebagai ideologi merupakan bagian dari proses sejarah, di mana manusia tidak selalu puas dengan nalar teks yang mati, dan kemudian berusaha menghidupkan teks tersebut melalui dialog dan pemaknaan yang lebih terbuka. Dari sinilah proses produksi makna (ilmu pengetahuan) terjadi, dari proses produksi makna baru kemudian mengejewantah sebagai ideologi baru umat. Persoalan kemudian, di mana letak karakteristik ideologi Islam dan apa hubungannya dengan ideologi-ideologi besar yang lain, artikel ini secara simplistik akan memetakan persoalan tersebut menjadi kerangka pikir yang mudah dipahami.

\section{Objektifikasi Ideologi}

Istilah ideologi terutama dilekatkan dengan aspek politik pemerintahan atau gerakan politik suatu negara. Di Indonesia misalnya, Pancasila diakui sebagai ideologi negara. Pancasila ini terdapat di dalam konstitusi (UUD 1945), tepatnya di dalam Pembukaan UUD 1945. Sebab itu, Pancasila menjadi cara pandang bangsa Indonesia, baik terhadap diri, lingkungan, negara, maupun dunia internasional. Seringkali jika terjadi konflik antar-kelompok di dalam masyarakat, Pancasila dijadikan rujukan untuk memeroleh titik temu. Sosialisasi Pancasila sebagai ideologi negara secara aktif dilakukan pemerintah melalui aneka cara.

1 Tim Dant, "A Modern Approach to Ideological Critique" dalam Knowledge, Ideology and Discourse: A Sociological Perspective (London: Routledge, 1991), 71. 
Pancasila merupakan salah satu contoh dari ideologi yang hidup di dunia ini. Pertanyaan yang layak diajukan lebih lanjut adalah, apa yang disebut dengan ideologi? Secara etimologis, ideologi berasal dari kata "ideo" dan "logos". Ideo berarti gagasan-gagasan, sementara logos adalah ilmu. Jadi, secara etimologis (asal-usul bahasa) ideologi berarti ilmu tentang gagasan-gagasan atau ilmu yang memelajari asal-usul ide. Ada pula yang menyatakan ideologi sebagai seperangkat gagasan dasar tentang kehidupan dan masyarakat, misalnya pendapat yang bersifat agama ataupun politik.

Selain makna etimologis, ideologi dapat dikatakan mengacu pada apa yang orang pikir dan percaya mengenai masyarakat, kekuasaan, hak, tujuan kelompok, yang kesemuanya menentukan jenis tindakan mereka. Ideologi berpengaruh terhadap tindakan politik tertentu. Apa yang orang pikir dan percaya mengenai masyarakat ini dapat berkisar pada bidang ekonomi, politik, sosial, dan filosofis.

Tidak ada pengertian yang pasti tentang ideologi, semua tergantung pada tujuan ideologi yang dimaksud. Dari tujuan tersebut kemudian melahirkan pengertian yang bisa dipahami. Franz MagnisSuseno melihat ideologi dalam tiga aspek: pertama, ideologi sebagai kesadaran palsu. Di kalangan filsuf Barat ideologi mempunyai konotasi negatif, klaim yang tidak wajar atau sebuah teori yang tidak berorientasi pada kebenaran melainkan kepada pihak yang memropagandakannya. Dalam kata lain ideologi dianggap sebagai sistem berpikir yang sudah terdistorsi, baik disadari atau tidak. Kedua, ideologi dalam arti netral, yakni ideologi yang dipakai sebagai "ideologi negara" seperti ideologi komunis, ideologi Pancasila. Ideologi dimaksud dianggap suatu sistem berpikir, nilai, sikap sebuah gerakan. Berbeda dengan ideologi pada umumnya, ideologi negara (ideological state apparatus) adalah bukan ideologi dalam arti yang sebenarnya yang merupakan ekspresi dominasi kelas, bukan pula untuk mengatur kelas sosial melainkan terjadi secara simultan dan kontradiktif dengan ideologi yang sebenarnya. ${ }^{1}$

Ketiga, ideologi dianggap sebagai keyakinan yang tidak ilmiah. Pemikiran ini muncul dari kalangan filsuf yang berhaluan positivistik yang memandang pikiran ideologi sulit diterima secara ilmiah karena tidak bisa diukur. Keempat, pikiran ideologis. Berbeda dengan ideologi, "ideologis" merupakan tuduhan bahwa argumentasi, teori atau nilai,

\footnotetext{
${ }^{1}$ Michel Pecheux, “The Mechanism of Ideological (mis-)Recognition” dalam Slavoj Zizek (ed.), Mapping Ideology (London: UK, 1994), 142.
} 
atau cita-cita tidak ditujukan demi kebenaran dan nilai etisnya melainkan demi kepentingan non-etis tertentu yang tersembunyi. ${ }^{2}$

Untuk memberikan pengertian yang lebih mendalam tentang ideologi, terlebih dahulu harus mendalami tentang sejarah munculnya teori ideologi. Ideologi menurut kalangan idealis adalah kumpulan ideide yang semata-mata merupakan produk pemikiran dan tidak memiliki basis meterial. Kaum idealis menganggap produksi ide terjadi sedemikian rupa dan tidak memiliki hubungan dengan kenyatan lain di luar alam pikiran, dan ide ini menentukan relasi manusia dalam perkembangan sejarah. ${ }^{3}$ Sementara menurut Karl Mannheim (18931947) ide-ide dan pemikiran bukan hasil murni kognisi tetapi dipengaruhi oleh konteks sosial. Ini bisa dilacak ke belakang melalui filsafat dari Larrain hingga Machiavelli pada abad 15. Pada abad 17 Francis Bacon telah memberi perhatian pada ciri sosial ilmu pengetahuan yang mengandung distorsi, seperti tampak dalam teorinya tentang "idol". Teori ini menjelaskan bahwa produksi pengetahuan yang melahirkan ide yang keliru atau terdistorsi tidak bisa dilepaskan dari konteks sosial. Teori Bacon dianggap sebagai versi awal tentang teori ideologi. ${ }^{4}$ Teori Bacon ini berkaitan dengan teori Mannheim tentang konsepsi partikular ideologi, dalam pengertian bahwa teori itu berkaitan dengan proses psikologis. Bacon tertarik pada ciri-ciri sosial dan psikologis pengetahuan yang menghasilkan falsifikasi.

Sementara itu Althusser mengembangkan tesis bahwa ideologi memresentasikan relasi-relasi imajiner individu dengan kondisi riil eksistensi mereka. ${ }^{5}$ Menurutnya juga, ideologi memiliki basis meterial yang ditandai dengan aparatus dan politik. Relasi imajiner adalah material, yaitu tindakan atau praktik individu yang mengalir secara bebas dari ide-ide. ${ }^{6}$ Menurut Althusser ilmu pengetahuan merupakan bentuk ideal yang memotivasi perjuangan dalam ideologi. Dalam

${ }^{2}$ Franz Magnis-Suseno, Filsafat sebagai Ilmu Kritis (Yogyakarta: Penerbit Kanisius, 1995), 229-231.

3 Tim Dant, "A Modern Approach”, 57.

${ }^{4}$ Ibid., 56.

5 Althusser merupakan pemikir ideologi modern, seangkatan dengan Jurgen Habermas yang dikenal dengan kritik ideologinya. Menurutnya, kritik ideologi menjadi tidak sekedar basis pada penumpahan cacian atas pemikir-pemikir yang telah merasionalisasi sistem ekonomi dan kelas yang eksploitatif. Konsen mereka ialah untuk memahami mekanisme yang menjaga kapitalisme tetap dan membuatnya tahan terhadap tantangan-tantangan. Ibid., 62 .

${ }^{6}$ Ibid., 59. 
pengertian ini, ilmu bukanlah katagori sosial dan bukan pula katagori epistemologis. Sebaliknya ilmu dapat dipahami sebagai respons terhadap kondisi eksistensi (material dan ideologis) yang menolak kondisi tertentu.

Sementara itu penisbatan ideologi sebagai kesadaran palsu tidak bisa dilepaskan dari pemikiran Marx. Dalam German Ideology, ${ }^{7}$ Marx dan Engels menjelaskan perkembangan historis kesadaran manusia dalam kaitan dengan material dan menyebutkan adanya dua tahap penting yang ditandai dengan pembagian kerja mental manual. Pada tahap pertama, kesadaran dan pemikiran dikaitkan dengan proses prilaku material, sementara tahap kedua kesadaran terpisah dari tindakan praktis. ${ }^{8}$ Menurut Marx, kesadaran juga bersifat ideologis, dalam pengertian bahwa dalam proses kehidupan historis keadaan manusia muncul terbalik seperti camera onscura, dan hantu yang dibentuk oleh manusia juga merupakan sublimasi (penghalusan) dari proses material mereka. Jadi ideologi menurut Marx (1818-1883) merupakan kesadaran yang mengacu pada nilai-nilai moral tinggi dengan menurut kenyataan bahwa di belakang nilai-nilai luhur itu tersembunyi kepentingan-kepentingan egois kelas-kelas penguasa. Nilai dan pandangan moral mempunyai fungsi mendukung strukturstruktur kekuasaan dalam masyarakat.

Menurut Magnis-Suseno ada tiga macam ideologi yang berkembang di dunia. Pertama, ideologi penuh atau juga disebut dengan ideologi tertutup. Ideologi tertutup tidak diambil dari masyarakat, melainkan merupakan pikiran sebuah elite yang harus dipropagandakan dan disebarkan kepada masyarakat. Ideologi tertutup tidak mendasarkan diri pada nilai-nilai dan pandangan moral masyarakat, melainkan sebaliknya baik-buruknya nilai diukur dari sesuai-tidaknya dengan ideologi itu. Ideologi tertutup harus dipacu oleh sebuah elite ideologis. Ciri khas ideologi tertutup bahwa klaimnya

\footnotetext{
${ }^{7}$ Mengutip tulisan Tim Dant, Ibid., 57.

${ }^{8}$ Ibid.

9 Magnis-Suseno, Filsafat sebagai Ilmu Kritis, 228. Pandangan Marx banyak dikritik khususnya oleh Jorge Larrain karena samar dan tidak jelas. Menurutnya, Marx mendekati konsep ideologi atas dasar karakter kontradiksionis dari realitas sosial yang dihasilkan oleh kekuatan produksi dan pembagian kerja. Ini membawa kepada karakter ideologi: solusi dalam pikiran untuk kontradiksi yang sulit dipecahkan dalam praktik.: ideologi adalah suatu proyeksi yang diperlukan dalam kesadaran tentang ketidakmampuan praktis menusia. Lihat Tim Dant, "A Modern Approach", 60.
} 
tidak hanya memuat nilai-nilai dan prinsip-prinsip dasar saja, melainkan bersifat konkret operasional. Artinya, ideologi tidak mengakui hak masing-masing orang, dan ideologi tertutup menuntut ketaatan tanpa reserve. ${ }^{10}$ Ideologi tertutup bersifat dogmatis, intoleran dan totaliter serta dapat digunakan untuk melegitimasikan kekuasaan sebuat elit ideologis.

Teori seperti Marxisme-Leninisme merupakan bentuk ideologi tertutup yang menganggap dirinya sebagai kebenaran yang tidak boleh dipersoalkan lagi, melainkan yang sudah jadi dan harus dipatuhi. ${ }^{11}$ Fasisme, sosialisme, dan ideologi "keamanan nasional" ala Amerika Latin juga termasuk ideologi tertutup meskipun memiliki perbedaanperbedaan formal yang cukup mendalam. Kapitalisme, liberalisme dan konservatisme jika membatasi terhadap ruang gerak manusia untuk menuju kekebasan disebut juga dengan ideologi tertutup. Tetapi sejauh ini liberalisme masih dianggap lawan dari ideologi tertutup, dan masih (dianggap) konsisten memerjuangkan nilai dan kekebasan.

Kedua, adalah ideologi terbuka. Cita-cita politik ideologi terbuka adalah menjamin kehidupan masyarakat untuk menentukan kehidupannya sendiri, kebebasan beragama dan berpandangan politik. Cita-cita itu bersifat limitatif dan bekerja melalui falsifikasi (artinya menetapkan batas-batas kebebasan, dengan tidak merugikan orang lain). Cita-cita itu tidak dibebankan kepada masyarakat, melainkan diangkat darinya melalui kesepakatan di antara mereka. Motivasi untuk mengikuti cita-cita itu tidak perlu dipacu, apalagi dipaksakan. ${ }^{12}$ Rumusan cita-cita itu adalah falsafah negara yang juga disebut dengan "ideologi terbuka". Ideologi terbuka bersifat inklusif, dan menerima semua pandangan yang berasal dari masyarakat selagi bertujuan untuk membela hak-hak asasi manusia, keadilan dan demokrasi.

Ketiga, ideologi implisit. Kedua ideologi di atas memiliki satu ciri bersama: merupakan cita-cita dan nilai yang secara eksplisit dan verbal dirumuskan, diperjuangkan, dipercayai dan dilaksanakan. Secara historis ideologi-ideologi eksplisit itu muncul bersamaan dengan zaman modern yang ditandai dengan rasionalisme dan sekularisasi. Pada era tradisional masyarakat memiliki keyakinan-kayakinan tentang hakikat realitas serta bagaimana manusia hidup di dalamnya. Meskipun keyakinan-keyakinan itu hanya implisit saja yang tidak

\footnotetext{
${ }^{10}$ Ibid., 232.

${ }^{11}$ Karl Mannheim, Ideology (London: Routledge dan Kegan Paul, 1989), 132.

${ }^{12}$ Magnis-Suseno, Filsafat sebagai Ilmu Kritis, 235.
} 
dirumuskan dan diajarkan, namun keyakinan itu dapat diresapi sebagai gaya hidup, berpikir bahkan beragama. Kayakinan dan cita-cita itu tidak eksplisit itu sering ada unsur ideologisnya karena mendukung tatanan yang ada, memberi legitimasi terhadap kekuasaan berdasarkan kelas atau lapisan sosial tertentu. Misalnya pandangan masyarakat Jawa tentang mikrokosmos (jagad cilik) dan makrokosmos (jagad gedhe) memuat paham tentang rahasia sebagai sumber keselarasan dan kesejahteraan masyarakat, dan dengan demikian melegitimasikan sistem kekuasaan monarki absolut. Oleh karena keyakinan dan nilainilai dasar itu melegitimasikan struktur non-demokratis tertentu. Jadi ideologi implisit menyangkut sejauh pandangan-pandangan yang tidak disadari secara eksplisit itu membenarkan struktur-struktur kekuasaan dalam masyarakat yang tidak adil, pandangan itu dinilai ideologis dan dengan demikian dinilai negatif. Bahkan dalam masyarakat modern seperti sekarang ini, ideologi implisit terjewantahkan dalam berbagai bentuk. Mereka tidak mau dihubungkan dengan ideologi yang sudah mapan, sebagai ideologi tertutup dan terbuka, atau dihubungkan dengan keyakinan (agama) tertentu. Mereka menyebut dirinya sebagai ideologi dan sumber ideologi, dan tidak mau dipaksakan dengan ideologi-ideologi lainnya. ${ }^{13}$

Terdapat dua karakter utama ideologi. Pertama, ideologi diformulasi dan ditaati dimaksudkan untuk tujuan tertentu. Pandangan dunia industrial misalnya, secara spontan akan memunculkan implikasi masyarakat yang terindustrialisasi. Dalam konteks masyarakat yang dibingkai oleh pandangan industrial kemudian muncul secara gradual masyarakat teknologi sosial. Pada saatnya kemudian, teknologi menjadi sentral di tengah masyarakat. Sementara itu, masyarakat industrial tersebut akan disertai dengan munculnya ideologi kapitalisme. Dari sinilah kemudian ideologi digunakan untuk menjustifikasi bentuk-bentuk sistem ekonomi industrial tertentu.

Kedua, ideologi digunakan oleh para proponennya untuk tujuan politik mereka. Dalam memerjuangkan politik, mereka cenderung menggunakan ideologi, dan bukan memakai pandangan dunia atau paradigma sosial. Berbeda dengan semua itu, ketika pandangan dunia atau paradigma diubah menjadi ideologi oleh sekelompok orang-

\footnotetext{
${ }^{13}$ Lihat David Wals, "Kata Pengantar" dalam David Wals, After Ideology: Recovering the Spritual Foundations of Freedom (Washington DC: The University of Catholic Press, 1990), xii.
} 
elite dominan, pemimpin gerakan sosial, kelas sosial yang kuat dan sejumlah kelompok lainnya-mereka menggunakannya sebagai instrumen pendorong dan penganut kekuasaan, tindakan dan tujuan mereka. Singkat kata, ideologi kemudian menjadi senjata politik. ${ }^{14}$

Keberpihakan terhadap suatu ideologi telah melahirkan klaim bahwa ideologi yang dianut oleh suatu negara/kelompok lebih unggul dari ideologi yang lain. Keberpihakan dan klaim kebenaran terhadap ideologi pada dasarnya menurut Zizek tidak bisa dilepaskan dari muatan kepentingan yang lebih besar yakni upaya memberikan pengaruh pada ideologi yang sudah ada, apalagi ideologi tersebut sudah dihubungkan dengan kepentingan politik dan ekonomi. ${ }^{15}$ Adanya klaim bahwa ideologi tertutup lebih populis, sementara ideologi lebih elitis merupakan pandangan yang bersifat apriori dan prematur, demikian sebaliknya ketika muncul pandangan bahwa ideologi tertutup bersifat elitis dan ideologi terbuka sangat populis juga subjektif. ${ }^{16}$ Karena pada kenyataannya di negara-negara yang menganut ideologi tertutup tidak selamanya gagal dan sukses, demikian pula bagi negara yang menerapkan ideologi terbuka. Namun secara teoretis, bahwa ideologi yang bercorak sosialis lebih besifat merakyat dan manusiawi, sementara ideologi kapitalis-liberal lebih banyak mementingkan kelompok yang dekat dengan kekuasaan untuk memeroleh akses yang lebih luas terhadap sumber-sumber produksi. ${ }^{17}$

\section{Membaca Peta Awal Ideologi Politik Islam}

Sebelum lebih mendalam memerbincangkan ideologi politik Islam, terlebih dahulu akan dikemukakan hubugan Islam dan negara. Perbincangan soal ideologi, lebih-lebih dalam Islam tidak bisa dilepaskan dari perbincangan sebuah negara. Hampir semua gerakan Islam modern tidak bisa dilepaskan dari gerakan yang berhaluan ideologis, khususnya melalui pembacaan terhadap teks dan sejarah perjalanan Islam pada masa-masa awal yang menjadi titik simpul Islam modern. $^{18}$

Beberapa dekade belakangan ini selalu muncul pertanyaan klasik yang memersoalkan hubungan Islam dan negara. Apakah Islam

\footnotetext{
14 Zainuddin Maliki, Narasi Agung: Tiga Teori Sosial Hegemonik (Surabaya: LPPAM, 2004), 21-22.

15 Zizek, Mapping Ideology, 176.

${ }^{16}$ Ibid.

17 Ibid.

${ }^{18}$ Lihat Achmad Jainuri, Orientasi Ideologi Gerakan Islam (Surabaya: LPAM, 2004), 3.
} 
sebuah agama atau negara, atau keduanya: agama sekaligus negara. Pertanyaan tersebut bukan pertanyaan latah atau mimpi di siang bolong, tetapi pertanyaan yang harus dijawab meskipun akhir jawaban itu secara akademis juga akan berpihak.

Dasar-dasar yang digunakan, baik bersumber pada al-Qur'ân maupun Hadith atau sejarah Islam tidak secara tegas menjelaskan apakah Islam sebagai agama dan negara, atau agama saja. Demikian pula tidak ada dasar yang menyatakan bahwa agama terpisah dari negara, atau negara terpisah dari agama. Demikian pula ketika merujuk pada tradisi sejarah sebagaimana ulama fiqh Sunnî menjelaskan tentang hubungan agama dan negara dengan mengambil contoh peristiwa-pristiwa politik dalam pemilihan/pengangkatan alKhulafâ' al-Rashidûn. Dalam kasus khalîfah sulit dibedakan antara urusan politik dan agama. Apakah berkumpulnya sahabat di Thaqîfah Bani Saî̀dah ${ }^{19}$ atas nama agama atau politik, atau kedua-duanya, memang sulit untuk dijelaskan secara komprehensif. Demikian pula apakah para khalifah itu memerintah atas nama agama atau kekuasaan semata juga tidak bisa diuraikan dengan menyeluruh, karena sulitnya membedakan antara urusan agama dan keduniaan. ${ }^{20}$ Begitu pula ketika Nabi masih ada, baik ketika berada di Mekkah maupun Madinah. Apakah Nabi memerangi kaum kafir yang membangkang itu atas nama agama atau kepala negara, atau keduanya, tidak bisa dijelaskan secara pasti.

Tapi satu hal yang perlu dicatat bahwa Islam lahir di sebuah wilayah yang tak bernegara, yang tidak memiliki aturan-aturan administratif sebagaimana layaknya sebuah negara. Islam lahir dengan mengusung peradaban modern dengan berusaha membawa aturanaturan itu di tengah masyarakat Arab yang sulit ditaklukkan dengan aturan-aturan. Aturan-aturan itu memerlukan kekuasaan yang mewakili komunitas mereka untuk melaksanakannya seperti hukuman bagi pencuri, pezina, dan yang lainnya. Fakta di atas tidak bisa dielakkan lagi ketika Islam berkembang begitu cepat sehingga memerlihatkan batas wilayah Islam dan non-Islam. Dari sinilah maka

\footnotetext{
19 Thaqîfah Bani Saî̀dah merupakan balai pertemuan orang Anșâr dan Muhâjirîn untuk membahas kepemimpinan umat Islam setelah Nabi meninggal.

${ }^{20}$ Kasus seperti ini juga terjadi pada agama manapun dan dalam kondisi apapun. Sementara dalam konteks Islam semakin tidak jelas karena dasar-dasar yang ada dalam al-Qur'ân maupun Hadîth tidak memberikan penjelasan yang memadai. Dalam Islam cuma mengenal istilah dâr al-ḥarb atau dâr al-Islâm.
} 
kemudian payung politik diperlukan, Islam adalah hukum dan setiap hukum atau aturan harus ada orang yang memerintah.

Nabi tidak memberikan aturan yang jelas tentang kepemimpinan sesudahnya. Demikian pula tentang kepemimpinan seperti apa yang layak dilaksanakan, dan kriterianya juga Nabi tidak memberi batasan. ${ }^{21}$ Munculnya khilafah dan penyebutan khaliffah merupakan hasil ijtihad para sahabat (Sabda Nabi antum a lam bi umûr dunyâkum) yang menganggap bahwa kepemimpinan sesudah Nabi tidak boleh kosong dan karenanya perlu seorang pemimpim yang bernama "khaliffah". Pertemuan di Thaqîfah tersebut untuk memilih khalîfah adalah pertemuan yang tidak direncanakan dengan matang, tergesa-gesa dan tidak memiliki dasar teologis yang kuat. Apalagi tidak semua unsur sahabat penting hadir dalam musyawarah tersebut.

Namun peristiwa di Thaqifah selalu dijadikan dasar dalam tradisi fiqh Sunnî khususnya dalam menganalogkan tradisi kepemimpinan: yakni pertama, khalifah tidak membicarakan negara sebagai institusi melainkan difokuskan kepada orang yang akan dibay'at untuk memerintah berdasarkan Kitab Allah dan Sunnah Rasul dalam jangka waktu yang tidak terbatas. Kedua, khalîfah hanya ada satu orang dalam wilayah Islam, sementara di bawahnya terdiri dari gunernur. Ketiga, khalîfah berdasarkan pilihan bukan "teks" (dalam tradisi Shî‘ah). ${ }^{22}$

Peristiwa politik di Thaqîfah dan kemudian melahirkan generasi khalîfah utama (dari Abû Bakar hingga 'Alî b. Abî Tâlib) menjadi dasar hukum politik dalam tradisi Sunnî yang kadang tanpa melihat makna-makna penting di balik semua peristiwa tersebut. Apakah sistem khalifah merupakan sebuah sistem politik Islam atau hanya sebuah ambiguitas politik. Apabila dikritisi secara mendalam baik tradisi sistem khalîfah pada masa-masa awal atau pemikiran politik Sunnî era belakangan, ambiguitas tersebut semakin menonjol melihat banyaknya kekurangan dalam sistem khalîfah. Ada beberapa poin penting yang perlu dicermati dalam tradisi khalîfah. Pertama, tidak ada batasan bagi jabatan khalîfah. Keempat al-Khalîfah al-Râshidah tidak memiliki batasan jabatan sehingga sulit diukur untuk dikatakan sebagai sesuatu yang ideal. Kedua, tidak ada pola atau tata cara bagaimana memberhentikan khalifah yang korup, tidak menjalankan undang-

21 Munculnya Hadîth al-aimmah min Quraysh lebih didasarkan pada pertimbangan bahwa masyarakat Arab tidak bisa tunduk selain pada suku Quraysh.

22 Muhammad Abid al-Jabiri, Agama, Negara, dan Penerapan Syariah, terj. Mujiburrahman (Yogyakarta: Pustaka Fajar Baru, 2001), 66-67. 
undang atau sudah tidak mampu lagi menjalankan tugas keseharian. Kasus al-Khulafâ' al-Râshidûn, tiga dari empat khalîfah adalah meninggal sebelum kekuasaannya habis. Ketiga, tidak ada metode yang tepat bagaimana memilih khalifah. Peristiwa di Thaqifah adalah peristiwa politik emergency, tergesa-gesa dan di luar rencana. Pergantian dari Abû Bakr ke 'Umar b. al-Khattâb adalah cara tidak ideal karena dapat menimbulkan fitnah, demikian pula pengangkatan 'Alî b. Abî Tâalib sebagai khalîfah tidak mencerminkan idealitas syarat-syarat pemimpin modern. Hanya cara yang dilakukan oleh 'Umar bisa dikatakan sebagai cara yang terbaik dibandingkan dengan ketiga cara sebelum dan sesudahnya. Keempat, tidak ada batasan wewenang seorang khalîfah. Mulai dari Abû Bakr hingga 'Alî pola kepemimpinannya mirip dengan "panglima perang" yang bisa memerintah kapan dan dalam situasi apa saja. Masalah pembatasan wewenang tidak sampai dipikirkan waktu itu karena umat Islam disibukkan dengan penaklukan dan ekspansi wilayah.

Realitas politik di atas melahirkan berbagai pandangan yang berbeda di kalangan umat Islam. Pandangan pertama menyatakan bahwa agama dan negara merupakan satu kesatuan yang tidak bisa dipisahkan. Pandangan kedua adalah agama dan negara berhubungan secara simbiotik, agama dan negara saling mengisi satu sama lain. Pandangan ketiga, bahwa agama terpisah dari negara (sekuler).

Perbincangan soal hubungan negara dan agama dalam Islam, khususnya pada masa-masa awal menjadi landasan dan pijakan pemikir Muslim untuk menentukan gerakan dan ideologi politik Islam. Perdebatan hubungan Islam dan politik khususnya keterkaiatannya dengan ideologi politik semakin menguat ketika ideologi-ideologi besar seperti Sosialis-Marxisme, Liberalisme, Kapitalisme masuk ke dalam ruang Muslim yang bersamaan dengan kesadaran umat Islam untuk menata kehidupan setelah sekian tahun lamanya tenggelam dalam keterpurukan sejarah. Ideologi-ideologi besar tersebut pada satu sisi menggeser keyakinan dan cita-cita yang ada dalam Islam, sebagian berusaha untuk mengawinkan antara Islam dan ideologi Barat, sementara ada sebagian yang lain berusaha untuk mengusung "Islam" sebagai ideologi murni. Yang dimaksud dengan ideologi di sini adalah interpretasi keagamaan dari berbagai ide yang saling berkaitan yang ada dalam aliran-aliran Islam, yang 
merefleksikan moral, kepentingan, serta komitmen sosial-politik. ${ }^{23}$ Pendekatan ini memandang bahwa semua unsur ideologi umumnya diterima sebagai formulasi filosofis yang bersifat tentatif, yang perumusannya disesuaikan dengan perubahan sosial-budaya.

Tentang ideologi politik Islam ini pada satu sisi tidak bisa dipisahkan dari kenyataan fakta-fakta politik pada masa Nabi yang kemudian dilanjutkan oleh al-Khulafâ' al-Râshidûn, juga adanya tuntutan terhadap dinamika yang berkembang di luar Islam. Dalam konteks ini, banyak muncul pemikiran baru ideologi politik Islam untuk mengggabungkan antara Islam dan ideologi Barat modern. Seorang pemikir politik modern Pakistan Abû al-A'la al-Mawdûdî menyatakan bahwa sangat sulit menerapkan konsep ideologi politik sebagaimana pada masa Nabi dan al-Khulafâ' al-Râshidûn di tengah umat Islam saat ini, apalagi jika ada tuntutan untuk menerapkan demokrasi sebagai semangat utama umat Islam. Karena Islam dan demokrasi pada satu sisi memiliki persamaan tapi pada sisi lain memiliki garis demarkasi yang jelas yang membedakan keduanya. ${ }^{24}$ Yakni soal kedaulatan Tuhan dan kedaulatan agama. Ideologi politik modern selalu mengedepankan prinsip kedaulatan manusia sebagai pijakan utama dalam proses pengambilan keputusan politik, sementara dalam Islam semua keputusan harus dikembalikan kepada ajaran utama Islam, yakni al-Qur'ân dan Hạdith. Dalam pengertian ini, keputusan manusia tidak berarti lagi apabila bertentangan dengan ajaran Islam. Untuk mencairkan kebuntuan ini al-Mawdûdî menawarkan apa yang disebut dengan teo-demokrasi, yakni demokrasi yang dilandasi dengan semangat ketuhanan, demokrasi yang bersumber dari ajaran-ajaran Islam. ${ }^{25}$

Al-Mawdûdî menyadari bahwa terdapat beberapa titik dalam ideologi politik Islam yang tidak selamanya beriringan dengan tuntutan demokrasi ala Barat sekarang. Sementara dia juga menyadari bahwa tidak mungkin kembali pada tradisi Nabi dan al-Khulafâ' alRâshidûn dalam mengembangkan ideologi politik. Pandangan ini sejalan dengan pemikiran politik Ibn Taymîyah, bahwa agama tidak bisa hidup tanpa negara dan dalam menjalankan sebuah negara tidak

23 Terrence Ball dan Richard Dagger, Political Ideologies and the Demodratic Ideal (New York: Harper Collins College Publishers, 1995), 9.

24 Lihat Abu A'la al-Maududi, Khilafah dan Kerajaan, terj. Muhammad Baqir (Bandung: Mizan, 1994), 440.

25 al-Maududi tidak spesifik menyebut istilah tersebut, namun pemeikiran-pemikiran politiknya selalu mengarah pada pandangan tersebut. Ibid. 
mungkin kembali lagi ke dalam tradisi awal umat Islam. ${ }^{26}$ Karenanya ideologi politik Islam akan selalu mengalami perkembangan sesuai dengan perkembangan umat Islam tersendiri.

Secara teoretis, ideologi politik Islam lebih dekat dengan ideologi sosialis, karena semangat yang dibangun oleh Islam adalah dalam rangka membela kaum mustad'afin (orang-orang lemah). Menurut Ibn Taymîah, apapun paham yang dianut oleh suatu negara harus mampu memelihara agama dan memerhatikan kesejahteraan masyarakat. ${ }^{27}$

\section{Berawal dari Fundamentalisme}

Ideologi politik Islam tidak dapat dilepaskan dengan gerakan fundamentalisme. Fundamentalisme memberikan ruang yang ikut andil dalam memerkuat ideologi politik Islam. Fundamentalisme lahir, tumbuh dan berkembang setelah Rasulullah meninggal, tepatnya 200 tahun sesudahnya.

Fundamentalisme selalu diidentikkan dan dihubungkan dengan agama. Baik di Barat maupun Islam, gerakan fundamentalisme sangat melekat dengan isu-isu agama seperti purifikasi, kebangkitan, reinterpretasi. Namun menurut Graudy, fundamentalisme merupakan fenomena yang tidak terbatas pada agama: terdapat fundamentalisme pada wilayah politik, sosial dan budaya. Karena baginya, fundamentalisme merupakan pandangan yang ditegakkan atas keyakinan, baik bersifat agama, politik atau budaya yang dianut pendiri yang menanamkan ajaran-ajarannya di masa lalu dalam sejarah. $^{28}$

Untuk mengelompokkan fundamentalisme sebagai fenomena budaya dan sosial yang berdiri sendiri memang tidak mudah, karena isu-isu agama sangat melekat dan selalu memiliki hubungan dengannya. Karena hampir semua fenomena bisa berhubungan dengan masalah sosial. Tugas sosiologi adalah mengelompokkan, mengkatagorisasi dan menempatkan secara sosial semua fenomena termasuk di dalamnya fundamentalisme pada agama.

Berbagai kasus di dunia Islam (khususnya Mesir dan Saudi Arabia) gerakan fundamentalisme berawal dari kelompok agama yang tidak

\footnotetext{
26 Qomarudin Khan, Pemikiran Politik Ibnu Taimiyyah, terj. Anas Mahyudin (Bandung: Pustaka, 1983), 309.

27 Ibid.

28 R. Graudy dalam Islam Fundamentalis dan Fundamentalis Lainnya, sebagaimana dikutip oleh Azyumardi Azra, Pergolakan Politik Islam dari Fundamentalisme, Modernisme hingga Post-Modernisme (Jakarta: Paramadina, 1996), 108.
} 
mampu beradaptasi dengan perubahan sosial dan kemudian melakukan respons dengan menggunakan tafsir agama. Kelompok ini kemudian muncul sebagai gerakan sosial yang terorganisir yang di dalamnya selalu menggunakan dasar dan argumen teologis untuk melawan tirani atau ketidakadilan sosial. Azyumardi Azra mengelompokkan gerakan ini menjadi dua tipologi, yakni pra-modern dan kontemporer (neo-fundamentalisme), dalam istilah lain juga disebut dengan fundamentalisme tradisional dan modern. ${ }^{29}$ Pramodern muncul disebabkan oleh situasi dan kondisi tertentu di kalangan Muslimin, karena itu lebih genuine dan inward oriented. Fundamentalisme kontemporer muncul sebagai reaksi terhadap penetrasi sistem dan nilai sosial, budaya, politik dan ekonomi Barat, baik melalui kontak langsung maupun melalui pemikir Muslim. ${ }^{30}$

Karena itu pembahasan fundamentalisme sebagai fenomena sosial di kalangan Muslim tidak bisa dilepaskan dari pembahasan mengenai masalah isu-isu agama yang melatari kemunculannya, yang berasal dari respons terhadap perubahan sosial yang begitu cepat.

Gerakan fundamentalisme menurut analisis Reisenbrodt bersumber dari perubahan sosial dengan segala akibat yang ditimbulkannya, kemudian melahirkan respons yang beragam di kalangan masyarakat. Dari respons ini, ada upaya untuk mengounter dengan argumen-argumen teologis dalam rangka counter terhadap perubahan tersebut. Counter tersebut dalam ilmu-ilmu sosial dianggap sebagai tesis kemudian melahirkan antitesis dan beranjak pada tesis lagi.

Untuk melihat kasus fundamentalisme sebagai fenomena sosial yang berkembang di dunia, akan digunakan sudut pandang Martin E. Marty, seperti yang dikutip Azyumardi Azra, untuk memetakan prinsip dan elemen gaya fundamentalisme. Menurutnya, ada empat prinsip dan gaya fundamentalisme: Pertama, prinsip fundamentalisme adalah oppositionalism (paham perlawanan). Semua bentuk modernitas, sekularitas dan tata nilai Barat yang dapat mengancam eksistensi agama akan dilawan.

Kedua, penolakan terhadap hermeneutika. Kaum fundamentalis menolak sikap kritis terhadap teks dan interpretasinya. Teks al-Qur'ân harus dipahami secara lateral-apa adanya. Ketiga, penolakan terhadap pluralisme dan relativisme. Bagi fundamentalisme, pluralisme

${ }^{29}$ Lihat Jainuri, Orientasi Ideologis, 73-74.

30 Azra, Pergolakan Politik Islam, 111. 
merupakan hasil dari pemahaman yang keliru terhadap teks kitab suci. Pemahaman dan sikap kegamaan yang tidak selaras dengan pandangan kaum fundamentalis merupakan bentuk dari relativisme kegamaan.

Keempat, adalah penolakan terhadap perkembangan historis dan sosiologis. Kaum fundamentalis berpandangan bahwa, perkembangan historis dan sosiologis telah membawa manusia semakin jauh dari doktrin literal kitab suci. Perkembangan masyarakat dalam sejarah dilihat sebagai as it should be bukan as it is. Dalam kerangka inilah masyarakat harus menyesuaikan perkembangannya, bukan sebaliknya, teks atau penafsiran yang mengikuti masyarakat. ${ }^{31}$

Sementara di dunia Islam, fundamentalisme tidak dapat dilepaskan dari sejarah Saudi Arabia dan Mesir, dua negara yang ingin ikut membangun ideology tersebut. Tokoh dan para ulama di dua negara tersebut berusaha untuk mengobarkan semangat kembali kepada ajaran al-Qur'ân dan Hadîth, atau yang dikenal dengan sebutan gerakan 'pemurnian'.

Ada hubungan yang sangat erat antara ajaran Saudi modern dengan semangat yang dikembangkan oleh Aḥmad b. Hanbal (780855) dan Ibn Taymîyah (1263-1328) yang sama-sama memelopori ajaran kembali pada al-Qur'ân dan Hadîth dengan meninggalkan ajaran yang berbau bid'ah dan khurafât. Sebelum munculnya kelompok fundamentalis modern akhir 1980-an dan awal 1990-an, kelompokkelompok radikal sudah lama berkembang dengan menjadikan institusi negara sebagai basis perjuangannya.

Secara umum ada tiga faktor yang melatari munculnya fundamentalisme di Saudi Arabia:

Pertama, bentuk kritik terhadap rezim yang berkuasa yang selalu mengatasnamakan agama sementara dalam praktiknya sudah keluar dari agama. Hak otoritatif terhadap satu kelompok agama, "Wahhabi" memicu absolutisme di kalangan masyarakat. Di samping itu juga kritik dilancarkan pada ruling family yang kemudian membius masyarakat bahwa tanpa Ibn Saud family Saudi tidak bisa berjaya. "Kita harus mengikuti Islam yang benar sebagaimana Islam yang dibawa oleh Nabi dan para sahabat, bukan mengikuti apa yang dikatakan oleh ulama yang korup" demikian oposisi mengatakan. "Wahabi untuk saat ini tidak punya otoritatif mengatasnamakan agama". ${ }^{2}$ Para aktivis

\footnotetext{
31 Ibid., 109-110.

32 Ibid., 6.
} 
meminta agar dipisahkan antara urusan politik, publik, pribadi dan bisnis. Sebab di sinilah letak terjadinya korupsi di lingkungan kerajaan. Aktivis meminta agar didefinisikan ulang aturan bernegara, permainan urusan pribadi dan publik, kejelasan aturan hukum dan sistem kekerabatan yang tidak jelas.

Kedua, sikap kritis karena pembatasan yang berlebihan terhadap semua gerakan sosial yang ada di Arab Saudi. Dengan kekuatan minyak yang melimpah, kerajaan membiayai besar-besaran operasi intelijen untuk membungkan kelompok-kelompok yang melakukan perlawanan terhadap pemerintah. Jaringan keluarga kerajaan juga ikut membantu memersempit gerakan kelompok radikal, meskipun akhirnya juga bisa lolos. Salah satu ungkapan yang selalu dikatakan oleh aktivis Saudi untuk melawan penguasa yang membela kepentingan Amerika: "Masyarakat (Arab) paling tahu tentang gurun. Mereka bisa survive sebab secara reguler keluarga menghabiskan tiga bulan di kamp gurun. Orang Amerika butuh air (mineral) untuk bisa hidup, orang Saudi Arabia cukup minum lumpur untuk bisa hidup".

Ketiga, sikap kritis dilancarkan kepada dominant narrative kerajaan. Sikap kritis pada konstruk sejarah Saudi Arabia yang penuh tipu muslihat dengan menggunakan dasar agama untuk memobilisasi dan menghipnotis masyarakat dengan segala dalih dan tipu daya. Sikap kritis ditujukan pada Abdul Aziz dan keluarga kerajaan yang selalu menganggap dirinya sebagai pemersatu antar suku, menikahi sekian istri demi menjaga kesatuan masyarakat Arab, penjaga agama, dan segala bentuk agitasi untuk melemahkan posisi tawar masyarakat. ${ }^{33}$

Sementara itu akar fundamentalisme di Mesir berawal dari pendudukan Napoleon Banoparte yang membawa angin modernisasi. Tak lama setelah pendudukan Napoleon, Muhammad Ali Pasya (1769-1849) menindaklanjuti modernisasi tersebut dengan berbagai cara di antaranya mengirimkan beberapa sarjana ke Eropa untuk belajar strategi perang, memerkenalkan model irigasi modern, membuka percetakan dan modernisasi pemerintahan. Muhammad Ali memerkenalkan apa yang disebut dengan "westernisasi". ${ }^{34}$ Cara yang digunakan oleh Muhammad Ali mendapatkan sambutan hangat di kalangan masyarakat Mesir, namun tidak sedikit yang mencurigai akan dampak negatif modernisasi tersebut. Di antara yang bersikap hati-

\footnotetext{
${ }^{33}$ Ibid., 6-8.

34 David Sagiv, Islam: Otentisitas Liberalisme, terj. Yudian W. Asmin (Yogyakarta: LKiS, 1997), 10.
} 
hati dan terkadang reaktif adalah Jamâl al-Dîn al-Afghânî (1839-1897) dan Muhammad 'Abduh (1845-1905). Di berbagai kesempatan khususnya ketika mengajar dan tulisan-tulisannya dalam al-Urwab alWuthqâ (tali yang kokoh), al-Afghânî menekankan bahaya yang akan ditimbulkan oleh Barat dan pengaruhnya di dunia Islam, dengan menekankan perlunya persatuan di kalangan umat Islam dalam rangka menangkal bahaya ini. ${ }^{35}$

Baik al-Afghânî maupun 'Abduh menyerukan kepada umat Islam agar kembali kepada ajaran agama yang benar dengan mendengungkan purifikasi dan meninggalkan bid'ah. Keduanya tidak menolak modernisasi, tapi bagaimana menyikapi dengan bijak isu-isu modern dalam kerangka keIslaman. Sementara murid 'Abduh, Muhammad Rashîd Rị̂a (1865-1935) yang menjadi penggerak kebangkitan Islam sesudahnya mementingkan perlunya penegakan kembali institusi khilâfah sebagai alternatif terhadap nasionalisme yang ia tantang. Premis yang digunakan adalah pemerintahan Islam adalah pemerintahan yang berasal dari wahyu, dan tidak ada kehidupan normal dan bahagia kecuali dengan pemerintahan semacam itu. Pemikiran Rị̂a sebagai bentuk kritik terhap model pemerintahan yang dikembangkan oleh pemerintah Mesir waktu itu.

Pada era ini, ada empat aliran politik yang menggelinding di Mesir. Pertama, aliran Barat yang menggemakan peniruan terhadap Barat dalam semua aspek kehidupan. Kedua, aliran religius anti-Barat yang berusaha merestorasi kejayaan Islam dengan cara kembali pada sumber-sumber agama. Ketiga, aliran nasionalis lokal yang tidak memberikan prioritas nasionalisme universal dan Pan-Islamisme. Keempat, nasionalisme Pan-Arab yang muncul pada akhir 1800-an dan menjadi intens pada abad 20 di mana banyak komunitas Kristen terlibat di dalamnya. ${ }^{36}$

Gerakan fundamentalisme merupakan respons atas modernitas yang berkembang di Mesir waktu itu. Secara umum Islam modernis dapat dikatagorikan dengan tiga hal. Pertama, kecenderungan untuk membatasi muatan tradisi otoritatif sebagaimana yang dikembangkan oleh pemahaman terhadap sumber-sumber utama ajaran Islam (alQur'ân-Hadîth). Hal ini bukan berarti menolak tradisi, tetapi

35 Ibid., 13. Lihat pula Daniel Crecelius, "Nonideological Responses of The Egyptian Ulama to Modernization", dalam Nikki R. Keddie, Scholars Saints and Sufis (California: University of California Press, 1978), 166-209.

${ }^{36}$ Sagiv, Islam Otentisitas, 24-5. 
berkecenderungan untuk melakukan seleksi yang ketat. Kedua, mereinterpretasi terhadap sumber-sumber otoritatif, khususnya terhadap beberapa sumber yang membawa implikasi luas munculnya pertentangan di kalangan Muslim seperti poligami, hukuman hadd, jihad, perlakuan terhadap orang murtad/kafir, pandangan terhadap isu-isu modern, kesaksian wanita, hak-hak suami istri. Beberapa reinterpreasi yang dikembangkan adalah memerbolehkan poligami dengan pertimbangan yang sangat ketat, memahami jihad sebagai defensive war, dan mengkaji ulang pandangan Muslim terhadap nonMuslim.

Ketiga, sikap apologetik yang menghubungkan aspek-aspek tradisi Islam dengan tradisi Barat, dan mengklaim bahwa Barat pada dasarnya mengambil tradisi Islam. Menurut Shepard, hal tersebut dianggap sebagai identifikasi sederhana sebagai penulis tentang Nasser yang menyatakan bahwa demokrasi di Yugoslavia meniru demokrasi langsung di Mesir. "Konsep demokrasi belakangan ini tidak asli lagi. Demokrasi yang original dapat ditemukan dalam demokrasi Islam awal". ${ }^{37}$ Praktik yang dikembangkan di Barat menurut para apologis adalah bersumber dari tradisi Islam sebagaimana konsep shûrâ. "Dalam terminologi politik modern shûrâ adalah demokrasi. Islam tidak menjelaskan bentuk, tipe dan tingkatan dalam demokrasi tetapi membiarkannya berada dalam pikiran Muslim dengan memertimbangkan aspek waktu dan tempat". ${ }^{38}$

Gema kebangkitan dan fundamentalisme mencapai puncaknya pada abad 20 ketika kekhalîfahan Islam Turki Ustmani bubar. Pada tahun 1928 gerakan al-Ikhwân al-Muslimûn (IM) muncul yang dipelopori oleh Hasan al-Bannâ. Al-Bannâ adalah aktivis pada kelompok kajian al-Mannâr yang dipimpin oleh M. Rashîd Riḍ̂a dan secara konsisten mengikuti ajaran-ajaran konservatif Rị̂a. Pada awalnya IM berkonsentrasi pada gerakan salafi dan sama sekali tidak masuk ke area politik, tapi belakangan ketika pengikutnya semakin banyak dan mendapat tempat di hati masyarakat Mesir, IM kemudian menjadi kelompok radikal yang dalam gerakannya selalu bersentuhan dengan wilayah kekerasan. ${ }^{39}$

Demikian pula ketika ide-ide Sayyid Quṭ (1906-1966) mulai masuk ke model gerakan IM. Meskipun awalnya bukan anggota, tapi

\footnotetext{
${ }^{37}$ Ibid., 415.

${ }^{38}$ Ibid.

${ }^{39}$ Leonard Binder, Islamic Liberalism (Chicago: Chicago University Press, 1988), 271.
} 
setelah kematian al-Bannâ justru Quṭb yang menjadi ikon gerakannya. Di samping para pendahulunya yang memengaruhi alam pikir Quṭ, ia juga dipengaruhi oleh al-Mawdûdî. ${ }^{40}$ Namun ada bukti lain bahwa Quṭb di sepanjang kehidupan intelektualnya sangat dipengaruhi oleh konsepsi keyakinan yang emosional, dan bahwa dia memberi sumbangsih besar bagi terbentuknya orientasi fundamentalis baru yang berpotensi melepaskan energi sosial yang dahsyat dalam bentuk gerakan massa yang tidak tunduk pada kendali negara dan tidak pula mengabdi pada elit dan alim ulama tradisional.

Salah satu doktrin Quṭb adalah konsep "Jâhilîyah modern", yakni modernitas sebagai "barbaritas baru". Meskipun istilah Jâhilîyah modern diadopsi dari al-Mawdûdî, tetapi konsep yang dikembangkan oleh Quṭb lebih berpengaruh. Menurut Quṭb Jâhilîyah modern adalah situasi di mana nilai-nilai fundamental yang diturunkan Tuhan kepada manusia diganti dengan nilai-nilai palsu (artificial) yang berdasar hawa nafsu duniawi. Jâhilîyah modern merajalela di muka bumi ketika Islam kehilangan kepemimpinan atas dunia, sementara pada pihak lain Eropa mencapai kejayaannya.

Untuk menumpas Jâhilîyah modern menurutnya, masyarakat Muslim harus melakukan taghyîr al-aqlìyah, yakni perubahan fundamental dan radikal, bermula dari dasar kepercayaan, moral dan etikanya. Dominasi atas manusia semata-mata dikembalikan kepada Allah, tegasnya Islam sebagai sistem holistik. Jihad harus dihadapkan dengan modernitas. Tujuan akhir jihad adalah membangun kembali "kekuasaan Tuhan" di muka bumi, di mana sharî́ah memegang supremasi: sharî‘ah bukan dalam pengertian sempit sebagai sistem hukum tetapi dalam pengertian lebih luas, yakni cara hidup menyeluruh sebagaimana digariskan Allah. ${ }^{41}$ Qutb memahami bahwa cara yang tepat untuk mengembalikan kekuasaan Allah di muka bumi dengan cara melakukan jihad secara total, fisik maupun non-fisik.

Gerakan fundamentalisme di Arab Saudi dan Mesir tidak berdiri sendiri, melainkan memiliki mata rantai yang kokoh dengan tokohtokoh sebelumnya. Secara ideologi kegamaan, gerakan Saudi dan Mesir mengacu pada gerakan Ahmad b. Hanbal yang hidup pada abad 8-9 M, kemudian gerakan ini secara sistematis diikuti oleh Ibn Taymîyah dengan semangat kembali kepada ajaran al-Qur'ân dan alSunnah secara autentik. Setelah itu muncul Muhammad b. 'Abd al-

\footnotetext{
40 Ibid., 270.

${ }^{41}$ Azra, Pergolakan Politik, 120-1.
} 
Wahhâb, pendiri gerakan Wahabi. Para era ini gerakan fundamentalisme lebih terbentuk dan memiliki akses yang sangat luas, sehingga fundamentalisme berkembang secara pesat di Saudi Arabia.

Sementara gerakan fundamentalisme di Mesir khususnya yang dilakukan oleh al-Ikhwân al-Muslimûn merupakan respons terhadap modernisasi dengan menggunakan argumen teologis untuk mengounternya. Sama seperti Saudi Arabia, gerakan di Mesir juga menjadikan Ibn Hanbal dan Ibn Taymîyah sebagai ikon dan spirit gerakan, khususnya dalam pembaruan melalui pemurnian ajaran Islam. Sementara sikap terhadap gerakan Wahhabi justru sebaliknnya, ada usaha untuk melakukan perlawanan karena alasan perbedaan sudut pandang.

Secara lebih spesifik, mengutip pendapat Abdul Chalik ${ }^{42}$, berikut ini adalah mata rantai tersebut.

\section{Mata rantai gerakan fundamentalisme di Saudi Arabia dan Mesir}



${ }^{42}$ Lihat Abdul Chalik, Islam dan Kekuasaan (Yogyakarta: Interpena, 2012), 45. 
Perbedaan mencolok antara periode al-Afghânî dengan al-Bannâ terletak pada model gerakan yang dikembangkan. IM sebagai organisasi sosial kemudian merambah ke dunia politik, dan akhirnya menjadi gerakan bawah tanah yang memiliki pengaruh luas seantero Mesir. Bahkan IM juga mengembangkan sayap pengaruh di kawasan Arab seperti Yordania, Suriah, Arab Saudi, dan Palestina. "Palestine Revolt 1936" dijadikan sebagai momentum perluasan pengaruh IM yang kemudian menjadi prototype gerakan-gerakan fundamentalis di banyak negara berpenduduk Muslim. Sesudah kematian Qutb tahun 1966, gerakan fundamentalis IM bukan berhenti, bahkan lebih radikal dan revolusioner, dan masih berlangsung hingga sekarang meskipun dengan nama dan model yang berbeda.

\section{Masa Depan Politik Islam Indonesia}

Perbincangan Islam sebagai ideologi politik mulai santer terdengar sejak munculnya Piagam Jakarta. ${ }^{43}$ Piagam tersebut merupakan teks rancangan undang-undang yang secara tegas menempatkan agama (Islam) sebagai dasar negara. Salah satu bunyi teks tersebut adalah, "......Ketuhanan, dengan kewajiban menjalankan sharî‘ah Islam bagi pemeluknya", ${ }^{44}$ Teks tersebut secara tegas menyatakan Islam sebagai filosofi, dasar, landasan bagi pemeluknya yang menjadi penduduk mayoritas di negeri ini. Namun, penggunaan tujuh kata tersebut terus mengalami perdebatan hingga akhirnya sidang konstituante pada taggal 2 Juni 1959 yang dipimpin Soekarno, dengan suara mayoritas, 263 setuju untuk kembali ke teks UUD yang lama dengan menghilangkan tujuh kata tersebut.

Perdebatan antara yang mengusulkan, menolak dan menerima tujuh kata dalam rancangan teks UU tersebut merupakan gambaran peta ideologis umat Islam pada masa-masa awal. Dari kalangan Islam di tim sembilan perumus UU, terpetakan ke beberapa kelompok Islam, yakni modernis, tradisional, fundamentalis dan nasionalis. Perdebatan antara menolak dan menerima memerlihatkan bagaimana

\footnotetext{
${ }^{43}$ Sebelum Indonesia secara resmi memerdekakan diri tahun 1945, Badan Penyilidik yang terdiri dari berbagai kalangan yang beranggotakan 9 orang, yaitu Hatta, Subardjo, Soekarno, Maramis, Kahar Muzakir, Wachid Hasyim, Abikusno dan Agus Salim menyuiapkan kerangka dasar Undang-Undang yang kemudian dikenal dengan sebutan Piagam Jakarta (Jakarta Charter). Lihat Ali Haidar, NU dan Islam Indonesia (Jakarta: Gramedia, 1994), 244.

${ }^{44}$ Ibid.
} 
ideologi organisasi memberikan pengaruh dalam perumusan sebuah ideologi negara.

Jauh sebelum rumusan rancangan UU tersebut mengerucut pada usaha formulasi hukum Islam sebagai ideologi negara, perdebatan ideologi politik Islam sudah mengemuka. Dua organisasi besar (Nahdlatul Ulama dan Muhammadiyah) yang lahir sebelum munculnya wacana sharî́ah Islam dalam rancangan undang-undang sudah terlebih dahulu terlibat dalam perbincangan serius soal ideologi negara. NU dan Muhammadiyah memiliki sejarah kelahiran yang berbeda yang kemudian diusung menjadi ideologi gerakan mereka. NU yang pada awalnya bermazhab pada $\mathrm{Hijaz}^{45}$ dan Muhammadiyah kepada Kairo ${ }^{46}$ dari sisi latar belakang keagamaan memiliki corak dan perspektif yang berbeda. NU dikenal dengan ideologi tradisional sementara Muhammadiyah dikenal dengan corak modernis. Perbedaan pandangan tentang ideologi negara juga tergambar ketika NU menjadi partai politik pada tahun 1955, sementara Muhammadiyah melebur ke Masyumi (meskipun tidak sedikit dari Ormas selain Muahmmadiyah masuk ke Masyumi).

Debat soal ideologi politik Islam baik di parlemen maupun di luar parlemen didominasi oleh dua kubu tersebut (NU dan Muhammadiyah), ${ }^{47}$ baik pada Pemilu 1971, era fusi partai tahun

45 Pada tahun 1922 sampai 1926, para aktivis dari berbagai organisasi dan perhimpunan mengadakan serangkaian kongres bersama yang disebut "Kongres alIslam" untuk membicarakan masalah penting yang menjadi keprihatinan bersama. Kongres di antaranya diadakan di Mekkah (Hijaz) dan Kairo. Para ulama pesantren di Jawa Timur cenderung untuk menghadiri kongres di Hijaz karena ada persamaan pandangan soal materi-materi yang dibahas, dan pada saat itulah kemudian membentuk "Komite Hijaz" yang merupakan cikal bakal kelahiran NU. Lihat Martin van Bruinessen, NU, Tradisi, Relasi Kuasa, dan Pencarian Makna Baru, terj. Farid Wajidi (Yogyakarta: LKiS, 1994), 33-35.

46 Sementara Muhammadiyah dan Sarekat Islam cenderung memilih kongres di Kairo, karena di antara paham pembaharuan Muhammadiyah sangat dekat dengan paham Muḥammad Rashîd Riḍâ. Ibid., 33.

47 Selain NU dan Muhammadiyah, sebenarnya masih banyak Ormas yang mengusung ideologi berbeda, sebagaimana Sarekat Islam (SI), Persis, LDII, dan beberapa Ormas kecil. Namun suara mereka tidak terlalu signifikan dan dari sisi gerakan lebih bersifat lokal dan insidentil. SI misalnya, setelah Tjokroaminoto meninggal, hanya sedikit para tokoh yang ikut mengembangkan Ormas tersebut dan bahkan hanya terpusat di Solo dan sebagian kecil di kota lain. Lihat Lathiful Khuluq, "Sarekat Islam: Its Rise, Peak, and Fall”, al-Jamiah, No. 60 (1997), 247-267. 
$1973{ }^{48}$ era Khittah NU tahun 1984. Namun demikian, kedua Ormas tersebut tidak mampu menembus kekuasaan Orde Baru yang selalu menggunakan tangan besi untuk melawan aktivis Islam yang berusaha untuk mengusung ideologi Islam dalam negara kesatuan Republik Indonesia. Debat soal ideologi politik Islam hanya sebatas wacana dan menjadi isu-isu partisan untuk memengaruhi publik, karena tidak mampu menembus level negara. ${ }^{49}$ Apalagi usaha pembungkaman melalui (pemaksaan) untuk menerima Pancasila sebagai satu-satunya ideologi negara oleh pemerintah dijalankan sangat efektif dengan memotong kekuatan politik di lembaga resmi seperti legislatif.

Sejak tahun 1990-an, berbagai unsur Islam memeroleh peluang yang semakin luas dalam ruang-ruang negara. Pergeseran posisi Islam yang semakin ke tengah dalam panggung politik ini sering disebut "politik akomodasi Islam". Setidaknya ada empat pola akomodasi yang menonjol: pertama, "akomodasi struktural", yakni dengan direkrutnya para pemikir dan aktivis Muslim untuk menduduki posisi penting dalam birokrasi negara. Kedua, "akomodasi infrastruktur", yakni penyediaan dan bantuan infrastruktur bagi kepentingan umat dalam menjalankan kewajiban agama mereka. Ketiga, "akomodasi kultural", berupa diterimanya ekspresi kultural Islam ke dalam wilayah publik seperti pemakaian jilbab, baju koko hingga ucapan al-salâm 'alaykum. Keempat, "akomodasi legislatif" yakni upaya untuk memasukkan aspek hukum Islam menjadi hukum negara, meskipun bagi umat Islam saja.

Setelah era reformasi yang sukses menumbangkan rezim Soeharto pada tahun 1998 dengan dibukanya kran demokrasi dan kekebasan berpolitik praktis, perbincangan Islam sebagai ideologi politik mencapai puncaknya. Bersamaan dengan itu, Ormas Islam yang selama Orde Baru tiarap dan lebih banyak bergerak di bawah tanah

\footnotetext{
48 Setelah Pemilu 1971, ada usaha untuk menfusi partai-partai oleh Orde Baru karena dianggap tidak efektif. Pada tahun 1973, kemudian lahir PPP yang merupakan gabungan dari NU, MI, PSII, Parmusi dan Perti. Sementara partai nasionalis dan Kristen bergabung dengan PDI. Lihat Saiful Muzani, "The Devaluation of Aliran Politics: Views of the Third Congress of PPP", Studia Islamika, Vol. 1, No. 3 (1994), 177-219.

${ }^{49}$ Dua tokoh sentral umat Islam pada era tersebut, Gus Dur dan Amien Rais hanya mampu mengusung isu-isu representasi politik umat Islam, atau yang dikenal dengan "Islam struktural". Sementara Gus Dur hanya bekutat pada wilayah pribumisasi Islam, atau yang dikenal dengan sebutan "Islam kultural" sebagai jawaban atas stagnasinnya peran politik pada era tersebut. Arif Affandi (peny.), Islam Demokrasi Atas-Bawah (Yogyakarta: Pustaka Pelajar, 1997), 2-19.
} 
bermunculan dengan agenda ideologi politik yang berbeda. Bersamaam dengan era Reformasi, muncul Ormas Majelis Mujahidin Indonesia (MMI), ${ }^{50}$ Hizbut Tahrir Indonesia (HTI), ${ }^{51}$ Laskar Ahlus Sunnah Waljamaah, Laskar Jihad, Front Pembela Islam (FPI), Dakwah Salafi. Hal yang sama juga terjadi pada partai politik, baik yang secara langsung berafiliasi dengan Ormas Islam maupun yang secara tersembunyi berdiri di belakang Ormas Islam. Baik MMI maupun HTI secara tegas mengusung agenda politik: legalisasi hukum Islam dalam sebuah negara, dan menganggap bahwa negara yang tidak menjadikan sharî‘ah sebagai UU dianggap bertentangan dengan Islam.

Baik MMI, HTI, FPI, Laskar Jihad yang sering disebut "Gerakan Islam Baru" (new Islamic movement) merupakan gerakan impor Timur Tengah melalui transmisi gerakan alumni di seluruh Indonesia. ${ }^{52}$ Melalui para alumni Timur Tengah, gerakan Islam ini dengan cepat menyebar ke masyarakat, baik melalui pesantren, madrasah, halâqah, hingga Ormas dan partai politik. Gerakan Islam tersebut selama ini masih tiarap dan mencari momentum untuk tumbuh dan berkembang sebagai alternatif atas reaksi pemerintah yang cenderung sekuler dan keluar dari ajaran Islam.

\section{Penutup}

Yang dimaksud dengan ideologi politik Islam di sini adalah interpretasi keagamaan dari berbagai ide yang saling berkaitan yang ada dalam aliran-aliran Islam, yang merefleksikan moral, kepentingan, serta komitmen sosial-politik. Ideologi politik Islam tidak bisa dilepaskan dari hubungan agama dan negara dalam Islam, terutama gerakan fundamenlaisme yang secara terorganisir baru muncul abad

50 MMI merupakan organisasi fundamentalis yang dipimpin oleh Abu Bakar Ba'asyir. Salah satu hasil Kongres MMI di Yogyakarta tahun 5-7 Agustus 2000, disebutkan bahwa wajib hukumnya melaksanakan sharî‘ah Islam bagi umat Islam di Indonesia dan di dunia pada umumnya. Sementara UUD 1945 buatan manusia, karena tidak sakral dan bisa berubah sesuai dengan tuntutan zaman. Lihat Abdur Rohim, "Fenomena Fundamentalisme Islam Indonesia: MMI", Akademika, Vol. 16., No. 2 (2005), 127-128.

${ }^{51}$ Hizbut Tahrir (HT)didirikan oleh Taqîy al-Dîn al-Nabhânî (1905-1977), mantan pengikut al-Ikhwân al-Muslimûn dan Hakim di Paletsina. HT Indonesia berusaha untuk melegalisasi kbilâfah dalam sebuah negara. Lihat Ainur Rofiq al-Amin, "Transmutation of Ideology Gerakan Hizbut Tahrir", Akademika, Vol. 16., No. 2 (2005), 110-115.

52 Secara jelas tentang sejarah transmisi ini lihat, M. Imdadun Rahmat, Arus Baru Islam Radikal: Transmisi Revivalisme Islam Timur Tengab ke Indonesia (Jakarta: Erlangga, 2002), 71-121. 
19 di Saudi Arabia dan Mesir namun benihnya sudah ditanam sejak era Ibn Hanbal, tiga abad setelah Nabi meninggal.

Dalam perkembangannya, muncul berbagai diversifikasi hubungan yang bermuara pada pengejewentahan ideologi politik Islam. Hubungan tersebut adalah: Pertama, hubungan yang bercorak skriptualis-rasional. Polarisasi ini berhubungan dengan pendekatan terhadap sumber al-Qur'ân dan Hadîth. Kecenderungan skriptualistikrasional melahirkan pemahaman tekstualistik dan literalistik, penasfsiran yang berorientasi pada bahasa. Kedua kecenderungan idealis-realis. Pendekatan pertama cenderung melakukan idealisasi terhadap sistem pemerintahan dengan menawarkan nilai-nilai Islam ideal. Termasuk dalam kecenderungan ini adalah penafsiran negara yang bersifat filosofis. Sementara kecenderungan realis menolak terhadap kecenderungan idealis, dan menerima semua kenyataan pemerintahan dalam Islam dengan konsekuensi memberikan legitimasi kekuasaan atau mengontrol kekuasaan. Ketiga, formalissubstantif. Konsep formalistik lebih mengedepankan bentuk dari pada isi. Pembentukan negara menurut paham ini dengan menampilkan simbol keagamaan dalam negara. Sementara kecenderungan substantif lebih menekankan isi daripada bentuk. Dalam wilayah ini, format negara bukan sesuatu yang penting melainkan nilai yang terkandung di dalamnya.

Dalam sejarah Islam Indonesia terdapat polarisasi yang sangat kaya. Sejak zaman pra-kemerdekaan, Islam sudah menunjukkan yang beraneka ragam yang dipresentasikan oleh Ormas atau Orsospol. Oleh para pengamat keberagaman Islam ini diidentifikasi dengan berbagai nama atau label. Ada Islam tradisionalis, Islam modernis, Islam puritan, Islam skriptualis, Islam substantif, Islam literal, Islam ekstrem, Islam militan, Islam abangan, Islam nasionalis hingga Islam liberal. Demikian pula ketika Islam sudah masuk pada area ideologi politik, baik yang secara terang-terangan memakai baju partai politik maupun Ormas Islam, maupun secara tersembunyi yang berusaha mengusung ideologi politik Islam.

\section{Daftar Rujukan}

Affandi, Arif (peny.). Islam Demokrasi Atas-Bawah. Yogyakarta: Pustaka Pelajar, 1997.

al-Amin, Ainur Rofiq. "Transmutation of Ideology Gerakan Hizbut Tahrir", Akademika, Vol. 16., No. 2, 2005. 
al-Jabiri, Muhammad Abid. Agama, Negara dan Penerapan Syari'ah, terj.

Mujiburrahman. Yogyakarta: Pustaka Fajar Baru, 2001.

al-Maududi, Abu A'la. Khilafah dan Kerajaan, terj. Muhammad Baqir. Bandung: Mizan, 1994.

Azra, Azyumardi. Pergolakan Politik Islam dari Fundamentalisme, Modernisme bingga Post-Modernisme. Jakarta: Paramadina, 1996.

Ball, Terrence dan Dagger, Richard. Political Ideologies and the Demodratic Ideal. New York: Harper Collins College Publishers, 1995.

Binder, Leonard. Islamic Liberalism. Chicago: Chicago University Press, 1988.

Bruinessen, Martin van. NU, Tradisi, Relasi Kuasa, dan Pencarian Makna Baru, terj. Farid Wajidi. Yogyakarta: LKiS, 1994.

Chalik, Abdul. Islam dan Kekuasaan. Yogyakarta: Interpena, 2012.

Crecelius, Daniel. "Nonideological Responses of The Egyptian Ulama

to Modernization", dalam Nikki R. Keddie, Scholars Saints and Sufis. California: University of California Press, 1978.

Dant, Tim. "A Modern Approach to Ideological Critique" dalam Knowledge, Ideology and Discourse: A Sociological Perspective. London: Routledge, 1991.

Haidar, Ali. NU dan Islam Indonesia. Jakarta: Gramedia, 1994.

Jainuri, Achmad. Orientasi Ideologi Gerakan Islam. Surabaya: LPAM, 2004.

Khan, Qomarudin. Pemikiran Politik Ibnu Taimiyyah, terj. Anas Mahyudin. Bandung: Pustaka, 1983.

Khuluq, Lathiful. "Sarekat Islam: Its Rise, Peak, and Fall", al-Jamiah, No. 60, 1997.

Magnis-Suseno, Franz. Filsafat sebagai Ilmu Kritis. Yogyakarta: Penerbit Kanisius, 1995.

Maliki, Zainuddin. Narasi Agung: Tiga Teori Sosial Hegemonik. Surabaya: LPPAM, 2004.

Mannheim, Karl. Ideology. London: Routledge dan Kegan Paul, 1989.

Muzani, Saiful. "The Devaluation of Aliran Politics: Views of the Third Congress of PPP", Studia Islamika, Vol. 1, No. 3, 1994.

Pecheux, Michel. "The Mechanism of Ideological (mis-)Recognition" dalam Slavoj Zizek (ed.), Mapping Ideology. London: UK, 1994.

Rahmat, M. Imdadun. Arus Baru Islam Radikal: Transmisi Revivalisme Islam Timur Tengah ke Indonesia. Jakarta: Erlangga, 2002.

Rohim, Abdur. "Fenomena Fundamentalisme Islam Indonesia: MMI”, Akademika, Vol. 16., No. 2, 2005. 
Abdul Chalik

Sagiv, David. Islam: Otentisitas Liberalisme, terj. Yudian W. Asmin. Yogyakarta: LKiS, 1997.

Wals, David. "Kata Pengantar" dalam David Walls. After Ideology: Recovering the Spritual Foundations of Freedom. Washington DC: The University of Catholic Press, 1990. 